\title{
Impact of quality assurance initiative on Pakistani universities
}

Usmani, Muhammad Abdul Wahid $₫$

King Saud University, Riyadh, Kingdom of Saudi Arabia (awusmani@yahoo.com)

Khatoon, Suraiya

Institute of Business Administration, Karachi, Pakistan (Suraiya.khatoon@yahoo.com)

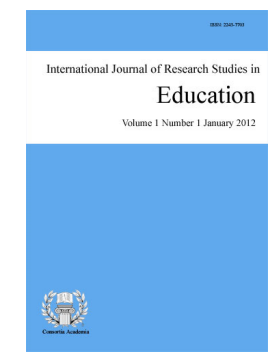

ISSN: 2243-7703 Online ISSN: 2243-7711

OPEN ACCESS

\section{Abstract}

Quality Assurance in Higher Education in Pakistan was formally initiated when Quality Assurance Agency was established under Higher Education Commission of Pakistan. This Quality Assurance Agency established Quality Enhancement Cells in public and private sector universities and they were given the task of conducting Program Evaluation through Self-Assessment using the guidelines provided by the QAA of Higher Education Commission. All the Quality Enhancement Cells were required to submit the Self-Assessment Reports of all the programs being offered at their respective university on set criteria. The current paper is a descriptive study which was conducted to review the impact of program evaluation on Pakistani universities. Data available with Quality Assurance Agency, Pakistan and field notes were used as tools to evaluate the efficacy and impact of quality assurance initiatives in Pakistani universities. The data shows that a very large number of programs in different universities prepared program evaluation reports and submitted for external review of the reports. External reviews resulted into action plans for rectifications identified during external review. Finally, the program evaluation reports were graded on a rubric in order to rank departments within a university. The study shows that quality assurance mechanism has got its firm roots at micro level i.e. at university level in Pakistan under the supervision of Quality Assurance Agency of Pakistan. Different programs of the universities run program evaluation cycle and report to their own Quality Enhancement Cells which in turn does a regular follow up of issues identified for assuring the provision of quality education. These cells finally report to the Quality Assurance Agency of the outcomes of program evaluation cycle.

Keywords: self-assessment; program evaluation; quality assurance; quality enhancement cell; educational quality in Pakistan 


\section{Impact of quality assurance initiative on Pakistani universities}

\section{Introduction}

Quality is a relative term which has been defined differently from perspectives of the various stakeholders or users. Lots of researches have been done to conceptualize quality and related terms. Definition of the quality from customers' point of view is different than the definition of the quality from the point of view of the producer. Similarly, the service provider would not have a similar opinion of the quality as that of the service user. To quote Vroeijenstijn, (1995, p.14) quality is 'a matter of negotiation between the different parties concerned'. This definition can rightly be applied to the field of education as it implies that different stakeholders which may include students, faculty, employers, governing bodies and society at large need to first identify their needs very clearly and the academics or the higher education institution, the service providers, then would take into account these requirements to devise mechanisms and procedures to ensure the provision of quality education in a particular discipline so that the qualified graduates would not turn out to be merely degree holders but would be equipped with all the necessary knowledge, skills and competences required to serve in the selected field both academic and professional. Then, again Vroeijenstijn, (1992) maintains that quality improvement and its maintenance or sustainability are the two core functions of the quality assurance which are carried out by implementing systematic, focused and organized processes of review and evaluation (Vroeijenstijn, 1992). Kekäle (2002, p. 66), too, extends the same by emphasizing that quality is something valuable which is always measured in relation to the 'requirements or expectations set by different users and stakeholders'. So the stakeholders' requirements or expectations from a certain program or service serve the function of a yardstick to measure what they are gaining in return. Therefore, the program evaluators do give it a due weightage to base the evaluation standards along with several other concerns.

Quality Assurance, one of the major and most common quality related functions, simply refers to an organized and methodical approach to quality' (Collins, 1994). Harman (1998) citing Brennan (1996) explains that the term quality assurance as the 'systematic management and assessment procedures' designed and implemented carefully to attain the quality in the specified domain or institute and thus to win the confidence and trust of its key stakeholders who are the individuals and groups having a major interest in that institution or system, and its achievements in the overall management and the results achieved (Harman, 1998, p. 346).

The term quality assurance has been echoing in higher education institutes for more than a decade (Frazer, 1995; Vroeijenstijn, 1995; Brennan, 1996). It has become not only one of the gravest concerns of the institutes offering degree programs in various disciplines but also a mandatory requirement of the regulatory and accreditation bodies of higher education institutes. Bornmann et al. (2006) who conducted a study to evaluate the overall result of multi staged evaluations have found out that the structured and systematic quality assurance procedures are essential for the higher education reforms for being useful, effective and rewarding (Bornmann, Mittag, \& Daniel, 2006). Another group of researchers supplement this very idea that concerns related to quality assurance in higher education have become a central focus in both 'developing and transitioning countries' (El-Khawas et al., 1998; El-Khawas, 2002).

Frazer (1997) provided the opinion that there are several reasons responsible to give rise to the external quality assurance. Some of the most important in them include a greater sense of accountability on higher education institutes part to satisfy their stakeholders' expectations, higher education institutes' needs for continuous improvement and the announcement to the prospective students and employers about the academic standard of a certain program or degree awarding institute through ranking or accreditation and above all, by doing so, informing the government or the funding bodies about their better decision as to where and how much funds to invest or allocate. Kells (1997) has also found out the link between higher education institutes' academic standards or 'performance indicators' and the funding resources. He concludes that the quality 
Impact of quality assurance initiative on Pakistani universities

assurance can yield better results if it becomes more focused and directed towards the desired changes and thus, it can be turned into a more fruitful exercise because the funding resources will automatically increase if the institute or the program manages to achieve its set objectives and performance indicators but if it is the vice versa, the link between the performance indicators and funding resources will decrease.

Quality assurance being formative in nature results in improving the quality related issues and leads to a sustainable quality enhancement in higher education institutions through effective functioning and decision making (Sarrico et al., 2010). These researchers believe that the quality assurance systems in any higher education institution, serves two main purposes: first that it helps the institution achieve the desired objectives and second that it enables the institutions to meet the requirements of its stakeholders.

Higher education is mainly concerned with three major domains of any course of study; teaching, learning and research. Quality assurance aims to develop and improve these areas (Schwarz, \& Westerheijden, 2007). Darwin et al. (2005) view quality assurance as a mandatory part of public education policies to fulfill educational needs of the citizens and therefore suggest that there should be strong liaisons between what institutions want to give or produce and how government educational policies and procedures can support them in achieving that set purposes. If this alignment is missing, citizens lose their interests as well as opportunities to improve themselves (Darwin \& Darrell, 2005). Ayeni (2012), in a recent research discussed some of the main features responsible for the sustainability of the quality assurance system in education that include a focused approach towards the attainment of predefined goals with effective strategic planning to achieve them and proper management of available resources to improve teaching and learning processes.

In addition to this, highlighting the factors being responsible to give rise to the growing concerns in quality assurance in the higher education; Nicholson (2011) cites multiple studies showing that the pressure from government and the job market has created an insight in the service providers in the field of higher education to prepare a work-force that is not only just degree holders but are qualified and equipped with essential knowledge, skills and attributes required to meet market challenges and who can contribute effectively towards the improvement of the country economy and as it has ultimately resulted into a greater increase in the education funding so the demand of accountability from the degree awarding institutions has also increased considerably. To serve this purpose, the higher education institutes need fully functioning quality assurance systems, processes and procedures to check and measure the level of the successful attainment of the program outcomes (Nicholson, 2011).

In Pakistan, Quality Assurance Agency was established by Higher Education Commission of Pakistan for assuring the quality of graduate and post graduate programs. Before the establishment of QAA agency, evaluation was not systematic in Pakistani higher education system. It was mainly individual focused (Usmani \& Khatoon, 2013). QAA of Pakistan decided to establish Quality Enhancement Cells at university level. These Cells were assigned to conduct Program Evaluation through Self-Assessment (Usmani et al., 2010). This paper focuses on the impact of quality assurance initiative of Quality Assurance Agency on Pakistani universities. The paper precisely addresses how Quality Enhancement Cells were established in universities and how they have contributed to program evaluation of different graduate and post graduate programs of Pakistani universities. The findings given here are based on the data compiled by the Quality Assurance Agency, Pakistan.

\section{Establishment of Quality Enhancement Cells and methodology of self-assessment}

Initially, Quality Assurance Agency, Higher Education Commission, Pakistan took initiative to establish Quality Enhancement Cells in 30 Public sector universities aiming to implement a quality assured system for all degree programs. Gradually, more universities were included phase wise. Now there are 87 universities altogether including private and public sector universities where Quality Enhancement Cells are fully functioning.

When these cells started working, the officials had to face resistance but gradually, through the frequent 
awareness sessions and training workshops conducted for different stakeholders such as faculty, department and institutional heads and higher governing authorities, a paradigm shift was noticed. They began to realize that the implementation of a structured quality assurance system is essential to solve many problems related to teaching-learning processes, resource management, and continuous assessment and evaluation. (Usmani, 2010)

To begin the self-assessment cycle, Quality Enhancement Cells requested head of departments of the programs to be assessed to nominate 3-4 faculty members to work on the preparation of the Self-Assessment Report. These nominees were called Program Team. These program teams were established for each academic program selected for program evaluation through self-assessment. As a next step to the self-assessment cycle, the program teams were provided with frequent trainings, hands on workshops, necessary material related to the Self-Assessment Report such as the Self-Assessment Report guidelines prescribed by the Higher Education Commission, copy of templates, tables for data collection, feedback forms etc. to prepare the program evaluation reports. With the help of the continuous support from the Quality Enhancement Cells, the Program Teams prepared Self-Assessment Reports and submitted to the Quality Enhancement Cells with all support documents.

The next phase of the self-assessment cycle began with the formulation of Assessment Teams. The Assessment Teams comprised of 2-3 senior faculty members of other department/institute and a subject expert from outside. These members were also trained to review and assess these reports in the light of the given checklists. Besides, in order to validate the findings of the Self-Assessment Report, the Assessment Teams were required to pay field visits to the concerned institute/department under evaluation. After these visits, they prepared their observation reports and submitted them to Quality Enhancement Cells. Based on their findings, the following Action/Implementation Plan was prepared that included problems identified, suggested rectification for each problem with specific date of implementation and resources required. This Action Plan was discussed further in the meeting of both Program Team and Assessment Team. After consensus, the signed copies were prepared and submitted to the concerned institutes to implement the suggested rectifications to the problems identified, to the Quality Enhancement Cells for further follow ups and to the Higher Education Commission for the third party validation and for their record.

\section{Table 1}

Self-assessment report action implantation plan

Self-assessment report implementation/ action plan

Name of the program:_ Name of the institute:

\begin{tabular}{l|c|c|c|c|c}
\hline S.\# & $\begin{array}{c}\text { Problems } \\
\text { identified }\end{array}$ & $\begin{array}{c}\text { Rectification } \\
\text { suggested }\end{array}$ & $\begin{array}{c}\text { Date of } \\
\text { implementation }\end{array}$ & $\begin{array}{c}\text { Responsible } \\
\text { body }\end{array}$ & $\begin{array}{c}\text { Resources } \\
\text { needed }\end{array}$ \\
\hline & & & & & \\
\hline & & & & & \\
\hline
\end{tabular}

Signature of the Chairman, assessment team:

Signature of the Head of the department:

Signature of the Director, Quality Enhancement Cell:

\section{Tabular output of quality assurance through self-assessment}

Quality assurance in higher education in Pakistan was initiated when Quality Assurance Agency, established under Higher Education Commission, Pakistan, took initiative of establishing Quality Enhancement Cells in different public and private sector universities phase wise. In Phase I, 10 universities were selected to establish Quality Enhancement Cells. In Phase II, 20 universities were chosen to start Quality Enhancement Cells. In Phase III, 17 more Quality Enhancement Cells were established in selected universities. The data is quite huge and is available with Quality Assurance Agency, Higher Education Commission.

The current paper deals only with the data available at Quality Assurance Agency, Pakistan till Phase III. 
Impact of quality assurance initiative on Pakistani universities

The main focus of this study is the findings of the study showing the large impact on over all performances of higher education institutes in Pakistani context.

Tables 2 to 4 show the gradual growth of Quality Enhancement Cells and their functioning.

Table 2

Phase I: Quality Enhancement Cells established during the year 2006

\begin{tabular}{ccccccc}
\hline $\begin{array}{c}\text { No of Quality } \\
\text { Enhancement } \\
\begin{array}{c}\text { Cells } \\
\text { established }\end{array}\end{array}$ & $\begin{array}{c}\text { No of } \\
\text { departments } \\
\text { selected for } \\
\text { program } \\
\text { evaluation }\end{array}$ & $\begin{array}{c}\text { No of } \\
\text { program. } \\
\text { evaluation } \\
\text { teams } \\
\text { formulated }\end{array}$ & $\begin{array}{c}\text { No of } \\
\text { program } \\
\text { evaluation } \\
\text { reports } \\
\text { prepared }\end{array}$ & $\begin{array}{c}\text { No of } \\
\text { assessment } \\
\text { teams } \\
\text { formulated }\end{array}$ & $\begin{array}{c}\text { No of } \\
\text { assessment } \\
\text { team reports } \\
\text { submitted }\end{array}$ & $\begin{array}{c}\text { No of action } \\
\text { plans devised }\end{array}$ \\
\hline 10 & 443 & 241 & 121 & 147 & 97 & 83 \\
\hline
\end{tabular}

The Table 2 shows that in Phase I, 10 universities were selected to establish Quality Enhancement Cells. These Quality Enhancement Cells selected 443 departments and / constituent institutes to conduct program evaluation. These departments/ constituent institutes were sent requests to nominate 3- 4 faculty members to prepare the reports and the nominees were called Program Evaluation Teams. Out of 443 departments, 241 Program Teams were formulated. The Program Teams were equipped with formal training and awareness on how to conduct program evaluation through Self-Assessment. They were also provided with the relevant material to run the exercise. Out of these 241 Program Teams, 121 teams prepared and submitted their program evaluation reports.

In the next stage, 147 Assessment Teams were formulated in 443 departments to review these reports. Out of 147 ATs, only 97 conducted reviews, paid field visits to validate the information presented in the program teams' reports and submitted their observations to Quality Enhancement Cells. These assessment team reports were further compiled, analyzed and used to prepare action plans to rectify the problems identified in each program. Total 83 action plans were devised based on the assessment team findings. These action plans categorically stated the problems identified after the self-assessment and its validation. Then, the program teams were asked to suggest rectification for each problem after the consultation with the concerned head of the department and the faculty members. Besides, they were also required to provide the specified timeline to implement the rectification suggested. Finally, they were also requested to mention the responsible body to implement the rectification along with the required resources to resolve the issues.

\section{Table 3}

Phase II: Quality Enhancement Cells established during the year 2007

\begin{tabular}{|c|c|c|c|c|c|c|}
\hline $\begin{array}{c}\text { No of } \\
\text { Quality } \\
\text { Enhancement } \\
\text { Cells } \\
\text { established } \\
\end{array}$ & $\begin{array}{c}\text { No of } \\
\text { departments } \\
\text { selected for } \\
\text { program } \\
\text { evaluation }\end{array}$ & $\begin{array}{c}\text { No of } \\
\text { program. } \\
\text { evaluation } \\
\text { teams } \\
\text { formulated }\end{array}$ & $\begin{array}{l}\text { No of } \\
\text { program } \\
\text { evaluation } \\
\text { reports } \\
\text { prepared } \\
\end{array}$ & $\begin{array}{c}\text { No of } \\
\text { assessment } \\
\text { teams } \\
\text { formulated }\end{array}$ & $\begin{array}{c}\text { No of } \\
\text { assessment } \\
\text { team reports } \\
\text { submitted }\end{array}$ & $\begin{array}{l}\text { No of action } \\
\text { plans devised }\end{array}$ \\
\hline 20 & 512 & 400 & 160 & 178 & 90 & 85 \\
\hline
\end{tabular}

Then, as evident from Table 3, in Phase II, 20 more Quality Enhancement Cells were established in selected universities where 512 academic programs were being offered. These programs were selected to conduct program evaluation through Self-Assessment. Out of these, 400 program teams were formulated. Out of these 400 Program Teams, 160 teams successfully prepared and submitted their Self-Assessment Reports. Likewise, to review these reports, in the 512 programs, 178 Assessment Teams were formulated. Out of 178 ATs, 90 conducted reviews; paid field visits to validate the information presented in the program teams' reports and submitted their observations to the Quality Enhancement Cells. After compiling and analyzing these assessment team reports, 85 action plans were devised and implemented to rectify the problems identified. 
Usmani, M. A. W., \& Khatoon, S.

\section{Table 4}

Phase III: Quality Enhancement Cells established during the year 2009

\begin{tabular}{|c|c|c|c|c|c|c|}
\hline $\begin{array}{c}\text { No of } \\
\text { Quality } \\
\text { Enhancement } \\
\text { Cells } \\
\text { established }\end{array}$ & $\begin{array}{c}\text { No of } \\
\text { departments } \\
\text { selected for } \\
\text { program } \\
\text { evaluation }\end{array}$ & $\begin{array}{c}\text { No of } \\
\text { program. } \\
\text { evaluation } \\
\text { teams } \\
\text { formulated }\end{array}$ & $\begin{array}{l}\text { No of } \\
\text { program } \\
\text { evaluation } \\
\text { reports } \\
\text { prepared }\end{array}$ & $\begin{array}{c}\text { No of } \\
\text { assessment } \\
\text { teams } \\
\text { formulated }\end{array}$ & $\begin{array}{c}\text { No of } \\
\text { assessment } \\
\text { team reports } \\
\text { submitted }\end{array}$ & $\begin{array}{l}\text { No of action } \\
\text { plans devised }\end{array}$ \\
\hline 17 & 247 & 98 & 46 & 48 & 3 & 3 \\
\hline
\end{tabular}

Finally, as shown in Table 4, in Phase III, 17 Quality Enhancement Cells selected 247 departments and/constituent institutes to conduct program evaluation. Out of 247 departments, 98 Program Teams were formulated. Out of these 98 Program Teams, 46 teams prepared and submitted their reports. To review these reports in 247 departments, 48 Assessment Teams were formulated. Out of 48 Assessment Teams, only 3 conducted reviews, paid field visits to validate the information presented in the program teams' reports and submitted their observations to Quality Enhancement Cells. After compiling and analyzing these Assessment Team reports, 3 action plans were devised.

\section{Impact of the quality assurance measure:}

The above discussion shows a rapid growth of quality assurance departments in the universities and their active contribution to the process of program evaluation. The measures taken to assure quality of the academic programs through internal and external evaluations have brought significant changes in terms of increasing the motivation and the contribution of the faculty and management as well as by arousing the sense of realization in them that the program core areas such as program mission, objectives and outcomes should not have been just available in the documented form but they needed to be operational at each stage. Likewise, the higher education institutes where this exercise was run also began to realize that this whole effort has helped them identify the areas for improvement which remained neglected before the implementation of these quality assurance measures.

Similarly, the self-assessment exercise helped the program teams see how well they were able to meet the intended objectives that the programs offered to do and how well students were able to perform in terms of knowledge, skills and desired attributes as documented in the program outcomes. This further led to the selection and application of appropriate measuring or assessment strategies or tools for each objective which was missing at most of the places before the implementation of the self-assessment practices. Hence, the improvements were very obvious in the up gradation of the academic standards in Pakistani higher education institutions. Moreover, this improvement further led to the increase in the level of public trust and funding bodies. While the internal quality assurance resulted into the gross improvement in the overall quality of academic programs, the external quality assurance via peer review and peer evaluation strengthened the areas which helped the institutes identify and meet their key performance indicators for the next cycle of evaluation and improve their ranking and ratings in the national QS ranking competition carried out by the Higher Education Commission, Pakistan.

However, the data also shows that not all the departments where self-assessment was introduced submitted reports. This difference is because Quality Enhancement Cells initiated self-assessment and program evaluation teams were nominated. However, either the program team got stuck or did not wish to proceed because of the amount of the work required. However, several programs completed their life cycle, worked as per their action plan to improve teaching and learning processes which ultimately led to the improved quality of the education. 171 action plans, so far, are in progress which is quite a good development towards the sustainability of the quality assurance system in a very small time of just five years. The data considered in this paper is only from 2006-2010 and it has been accessed through the Quality Assurance Agency, Higher Education Commission, Pakistan. Since the data for the recent years is still in the process of compilation, it is expected such growth of Quality Enhancement Cells and their program evaluation in their respective universities would have yielded 
much more positive results and the degrees from these universities would have carried more weight in the employment market.

\section{Conclusion}

From the above discussion and interpretation of the data, it may be concluded that as quality assurance has become a growing concern for higher education institutes all over the world, it has provided the degree awarding institutes with a challenge for healthy competition leading to provision of sustainable quality education. In Pakistani universities, the work on quality assurance is not much advanced though; it has started penetrating deeply in their roots and the initiative taken by Quality Assurance Agency by establishing Quality Enhancement Cells has worked as a fertile soil to yield fruitful results. Though not all the academic programs are being evaluated through self-assessment, those which have been through this process have improved significantly and if this practice is sustained as is expected, more rapid changes will be observed.

\subsection{Significance and areas for further investigation:}

The study is significant as it highlights the role of QAA of Higher Education Commission of Pakistan in introducing systematic program evaluation through self-assessment. This model of Quality at university level and its results would certainly provide positive input to other QA experts and QA agencies of the world. The study is based on a baseline data which provides orientations as to how Pakistan QA system is progressing in higher education. There is a need to conduct meta-evaluation of the program evaluation through self-assessment in order to see how this initiative has imbedded into the system of higher education and how stakeholders have felt the change in the overall output from higher education institutions in Pakistan.

\section{Reference}

Ayeni. A. J. (2012). Improving school and community partnership for sustainable quality assurance in secondary schools in Nigeria. International Journal of Research Studies in Education, 1(2), 95-102. http://dx.doi.org/10.5861/ijrse.2012.v1i2.49

Bornmann, L., Mittag, S., \& Daniel, H. D. (2006). Quality assurance in higher education - Meta evaluation of multi-stage evaluation procedures in Germany. Higher Education, 52(4), 687-709. http://dx.doi.org/10.1007/s10734-004-8306-0

Brennan, J. (1996). Quality assessment, authority and change. In P. A. M. Maassen \& F. A. van Vught (Eds.), Inside academia. New challenges for the academic profession (pp. 291-304). Management and Policy in Higher Education. De Tijdstroom, Utrecht.

Collins, P. (1994). Approaches to quality. The TQM Magazine, pp. 6-3. http://dx.doi.org/10.1108/09544789410057881

Daniel, H. D., Mittag, S., \& Bornmann, L., (2007). The potential and problems of peer evaluation in higher education and research. In A. Cavalli (Ed.), Quality assessment for higher education (pp. 71-82). Portland Press Ltd.

Darwin, D. H., \& Lewis, D. R. (2005). Quality assurance of higher education in transition countries: Accreditation - accountability and assessment. Tertiary Education and Management, 11(3), 239-258. http://dx.doi.org/10.1080/13583883.2005.9967149

El Khawas, E., Pietro-Jurand, R. de, \& Holm-Nielsen, L. (1998). Quality assurance in higher education: Recent progress challenges ahead. Washington, DC: The World Bank.

El-Khawas, E. (2002). Quality assurance for higher education: Shaping effective policy in developing countries. In D.W. Chapman \& A. E. Austin (Eds.), Higher education in the developing world: Changing contexts and institutional responses (pp. 197-215). Westport, CT: Greenwood Publishing Group Inc.

Frazer, M. (1995). Quality in higher education: An international perspective. In D. Green (Ed.), What is quality in higher education? (pp. 101-111). Bury St. Edmunds, Suffolk: The Society for Research into Higher Education \& Open University Press. 
Usmani, M. A. W., \& Khatoon, S.

Frazer, M. (1997). Report on the modalities of external evaluation of higher education in Europe: 1995-1997. Higher Education in Europe, 22(3), 349-401. http://dx.doi.org/10.1080/0379772970220308

Harman, G. (1998). The management of quality assurance: a review of international practice. Higher Education Quarterly, 52(4), 345-364. http://dx.doi.org/10.1111/1468-2273.00104

Kekäle, J. (2002). Conceptions of quality in four different disciplines. Tertiary Education and Management, 8, 65-80. http://dx.doi.org/10.1080/13583883.2002.9967069

Kells, H. R. (1995). Building a national evaluation system for higher education: Lessons from diverse settings. Higher Education in Europe, 20(1-2), 18-26. http://dx.doi.org/10.1080/0379772950200104

Nicholson, K. (2011). Quality assurance in higher education: A review of the literature. Retrieved from http://cll.mcmaster.ca/COU/pdf/Quality\%20Assurance\%20Literature\%20Review.pdf?referer=https\%3A $\% 2 \mathrm{~F} \% 2 \mathrm{Fscholar}$.google.com.pk\%2F

Sarrico, C. S., Maria, J. R., Teixeira, P. N., \& Margarida, F. C. (2010). Assessing quality and evaluating performance in higher education: Worlds apart or complementary views? Minerva, 48(1), 35-54. http://dx.doi.org/10.1007/s11024-010-9142-2

Schwarz, S., \& Westerheijden, D. F. (Eds). (2007). Accreditation and evaluation in the European higher education area. Springer.

Usmani, A.W., Khatoon Suraiya, Shamot, M., Zamil, M., (2010). Towards a network of quality assurance in higher education: A Pakistani model. Archives Des Sciences, 65(7), 224-229.

Usmani, M., A., W. \& Khatoon, S. (2013). Educational evaluation in Pakistani higher education context. Contemporary Educational Researches Journal, 3(1), 12-20.

Vroeijenstijn, A. I. (1992). External quality assessment, servant of two masters? The Netherlands perspectives. In A. Craft (Ed.), Quality assurance in higher education: Proceedings of an international conference (pp. 120-146). London: Falmer Press.

Vroeijenstijn, A. I. (1995). Improvement and accountability: Navigating between Scylla and Charybdis. Guide for external quality assessment in higher education. Higher Education Policy Series. Jessica Kingsley, London. 